\title{
FACTORS STIMULATING FARMERS IN APPLYING FOR THE MEASURE "SETTING UP OF YOUNG FARMERS" IN THE WIELKOPOLSKIE VOIVODESHIP
}

\author{
EWA KIRYLUK-DRYJSKA \\ PATRYCJA BEBA \\ MONIKA MAŁGORZATA WOJCIESZAK
}

\begin{abstract}
The aim of the study was to determine synthetic indicators of development of agriculture and rural areas diversifying farmers' activity in applying for support under the measure "Setting up of young farmers" under the RDP 2007-2013 in gminas of Wielkopolskie Voivodeship. The research covered 207 rural and urban-rural gminas. The synthetic indicators characterising agriculture and rural areas were identified for each gmina. The presented research results show that the frequency of application for the EU funds under the analysed measure has higher values on areas dominated by intensive farming and favourable demographic structure. It is lower, though, for gminas with well-developed entrepreneurship and organic farming .
\end{abstract}

Keywords: Rural Development Programme, facilitating the start of young farmers, farmers' activity.

JEL codes: Q01, Q14, Q18.

\footnotetext{
Dr hab. Ewa Kiryluk-Dryjska, Uniwersytet Przyrodniczy w Poznaniu, Wydział Ekonomiczno-Społeczny, Katedra Ekonomii i Polityki Gospodarczej w Agrobiznesie; ul. Wojska Polskiego 28, 60-637 Poznań (ewa.kiryluk@up.poznan.pl).ORCID iD: 0000-0003-4353-8196.

Dr Patrycja Beba, Uniwersytet Przyrodniczy w Poznaniu, Wydział Ekonomiczno-Społeczny, Katedra Ekonomii i Polityki Gospodarczej w Agrobiznesie, ul. Wojska Polskiego 28, 60-637 Poznań (patrycja.beba@up.poznan.pl). ORCID iD: 0000-0001-8120-3683.

Dr Monika Małgorzata Wojcieszak, Uniwersytet Przyrodniczy w Poznaniu, Wydział Ekonomiczno-Społeczny, Katedra Ekonomii i Polityki Gospodarczej w Agrobiznesie; ul. Wojska Polskiego 28, 60-637 Poznań (monika.wojcieszak@up.poznan.pl). ORCID iD: 0000-0002-9962-2648.
} 


\section{Introduction}

Poland's accession to the European Union has brought about new development opportunities for the Polish agriculture through the implementation of numerous instruments of the Common Agricultural Policy as well as the availability of funding to be applied for by farmers. Under the financial framework 2007-2013, a significant part of financial aid provided for in the CAP was earmarked for the implementation of the Rural Development Programme. The rural and agriculture development supported under the programme included a measure "Setting up of young farmers". It was assumed that support for young people (with relevant agricultural qualifications) in taking over and establishing farms would stimulate structural changes in the agricultural sector, while increasing its competitiveness. Young people, who remain on the farm, should be able to quickly acquire the necessary knowledge and skills enabling them to effectively manage agricultural production. These assumptions were to some extent included in the form of eligibility criteria for potential support beneficiaries in the RDP 2007-2013. As per measure 112 support was available to people who only planned to take over a farm and start-up (for the first time) agricultural business or persons that on the day of submission of the support application already had a farm, but had started agricultural business operations no earlier than 15 months prior to submission of the support application (Journal of Laws of 2015, item 895). Major aspect was also the age criterion, because the EU funds were available to people that were below 40 and had adequate qualifications. What should be stated is that the taken over farm had to have larger utilised agricultural area than the average for a given voivodeship and smaller than 300 ha (Ministerstwo Rolnictwa i Rozwoju Wsi, 2016). Submission of a farm development plan and graduation from an agricultural school ${ }^{1}$ by the person applying for support preconditioned granting the support. Another vital criterion was presentation of a farmer declaration regarding environmental protection, hygiene and conditions for keeping animals on a farm.

Farmers were granted support in a form of one-off payment of PLN 100,000, which could have been earmarked for a number of different investment measures ${ }^{2}$. Additionally, as of 2007 it is obligatory to present a business plan, which precisely determines and indicates funds allocation purpose, i.e. the target for allocation of $70 \%$ of the support amount that has to be spent over 3 years from the date of support payment ${ }^{3}$. It is clear that this action was aimed not only at improvement

\footnotetext{
${ }^{1}$ If such qualifications were lacking, it was possible to supplement them within 36 months from the date of receipt of the decision.

${ }^{2}$ These include construction, reconstruction, renovation combined with modernization of buildings or structures used for agricultural production, purchase of machinery, equipment, equipment for agricultural production, storage, drying, warehousing, preparation of agricultural products for direct sale, setting up or equipping orchards or perennial plantations, purchase, installation or construction of technical infrastructure elements directly affecting the conditions of agricultural activity, purchase of a basic herd of farm animals - related to the start of animal production or genetic progress in the scope of production (Journal of Laws of 2015, item 895).

${ }^{3}$ The final settlement of the investment was based on the assumptions contained in the business plan and the results of the on-site inspections, which confirmed whether the farmer had implemented the planned project in accordance with the farm development plan.
} 
of the age structure of farmers in Poland, but also at improvement of the rather unclear pro-investment character of measures.

According to Eurostat data for 2016, $10.2 \%$ of all farms in Poland were run by young farmers (under 35 years of age) ${ }^{4}$, while $11.7 \%$ of them were run by farmers aged 65 and more. These figures show that the agricultural population is aging, which necessitates the implementation of programmes to hinder this trend (Frye, 2013).

Brodzinska and Lewczuk (2002) showed that the area structure of farms belonging to young people is much better than the structure of farms in general. For this type of farms, technical equipment is also more effectively used. This complies with the findings of Katchova and Ahearna (2015), who proved that young farmers show a greater tendency to enlarge farms, both by purchase and lease, which has a positive impact on the agrarian structure. Young farmers also use technical equipment more efficiently on their farms. Dellapasqua (2010) is of the opinion that young farmers to the greatest extent contribute to supporting innovation and growth in farm efficiency.

Results of literature research show that young farmers understand the need for introducing changes on farms, are well-prepared in professional terms and show pro-innovative and entrepreneurial attitudes (Miś, 2016; Rudnicki, 2009; Adamowicz and Szepeluk, 2016).

Therefore support addressed to young farmers is well-grounded and should help to modernize agricultural structures in Poland.

The need for support of agricultural activity conducted by young farmers in Poland could be seen already in the first structural programmes funded by the EU. In 2004-2006, funds for facilitating the launch of agricultural activity by young farmers could be obtained under the "Restructuring and Modernization of the Food Sector and Rural Development" Sectoral Operational Programme. Almost 19,000 applications were submitted under this programme throughout Poland, and a total of PLN 707.6 million ${ }^{5}$ was paid out to farmers. This was approx. $3.7 \%$ of the total support for structural measures aimed at rural and agriculture development, cofinanced by the $\mathrm{EU}^{6}$. Since the launch of the call for proposals under the measure "Setting up of young farmers", implemented in Poland as part of the RDP 2007$-2013,52.7$ thousand applications were submitted for the total amount of PLN 4,346 million ${ }^{7}$. Payments under this measure amounted to PLN 3,189 million, which accounted for $4.4 \%$ of the total budget for the RDP ${ }^{8}$.

The Wielkopolskie Voivodeship was the second largest region with the greatest number of submitted applications (15\% of applications submitted nationwide), as

\footnotetext{
${ }^{4}$ In the Wielkopolskie Voivodeship this is $43 \%$ and is much higher than the avarage for Poland.

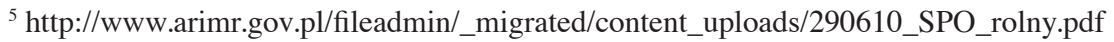

${ }^{6}$ In 2004-2006, structural measures aimed at rural and agricultural development were implemented also under the Rural Development Plan.

7 http://www.arimr.gov.pl/fileadmin/pliki/wdrazane_programy_sprawozdania/PROW_2007-2013/MR/2701 2016_MR_7-13.pdf

${ }^{8} \mathrm{http} / / /$ www.arimr.gov.pl/fileadmin/pliki/zdjecia_strony/223/Sprawozdanie_ARiMR__2016.pdf
} 
well as an area with the largest number of decisions on granting bonuses for young farmers (Grontkowska, Frania and Bagieński, 2016) ${ }^{9}$. According to data from the Agency for Restructuring and Modernisation of Agriculture (ARMA) for 2014, these funds were used mainly by people aged 19-25.

The measure continues to be implemented under the current financial framework (2014-2020 $)^{10}$. In total, PLN 3,096.9 million has been earmarked for its implementation, which is 5.4\% of the RDP budget for 2014-2020. The relative increase in funding under successive financial frameworks (despite a reduction in the RDP financial envelope for 2014-2020 by approx. PLN 14.4 billion compared to the RDP 2007-2013) confirms that this type of funding plays an important role in the development of the Polish agriculture.

The effectiveness of support for changes in agriculture, implemented through structural programmes, depends on the level of financial aid applied for and obtained by farmers. Determinants of support absorption have been discussed in literature by numerous authors. Kozera (2011) divides these determinants into two groups: internal and external. Internal factors depend on the beneficiary and his/her individual decisions. These include historical, natural, urban and social constraints.

This differentiation conditions the choice of a research method for absorption of the CAP funds. In case of internal factors, the most often used method of behavioural economics, indicating which factors motivate beneficiaries to or discourage them from taking up activities. Bielecka (2006), analysing internal conditions, concludes that factors discouraging beneficiaries from applying for support include changes in the documentation and rules of holding calls for proposals as well as complexity of the application process. Kozera (2011) proves that a factor effectively hampering application for support is passivity of the local community.

Analysis of external conditions of resources absorption requires determination of the impact of broadly-conceived environment on the actions of potential beneficiaries. Most commonly this environment is described by adequately selected statistical data at different levels of aggregation. For example, Bielecka (2006), Czubak and Kiryluk-Dryjska (2009), Wojewodzic (2016) and Rudnicki (2013) point to considerable regional differentiation of farmers' activity as regards obtaining support throughout Poland, and its relationship with differences in the level of agricultural development in the regions. The authors conclude that farmers from regions with a relatively higher level of agricultural development benefit from EU financial support more than those from regions with less developed production structures. Grontkowska, Frania and Bagieński (2016), Wojewodzic (2016), and Adamowicz and Szepeluk (2016), researching voivodeships or macroregions, point out that activity in application for support under the measure "Setting up of young farmers" is positively correlated with the average farm size of the beneficiaries. Wojewodzic

\footnotetext{
${ }^{9}$ In line with the Regulation of 18 March 2009 on allocation of funds from the Rural Development Programme for 2007-2013 the envelope of funds for the Wielkopolskie Voivodeship amounted to EUR 8,484,105.

${ }^{10}$ The support was given a new name (Bonus for young farmers) and is a submeasure of the Farm and Economic Activity Development measure.
} 
(2016), on the example of the Małopolska and Pogórze macroregion, indicated convergence between the frequency of application for support and the number of beneficiaries of structural pensions.

This paper attempts at an analysis of external factors of resources absorption under the measure "Setting up of young farmers" at the level of gminas (communes) of the Wielkopolskie Voivodeship. Identification of area-specific factors that encourage farmers to apply for support or discourage them from it may help to take appropriate measures to mobilize potential beneficiaries to apply for funding.

The purpose of the paper is to determine synthetic indicators of the development of agriculture and rural areas that diversify farmers' engagement in applying for support under the measure "Setting up of young farmers" provided for the RDP 2007-2013, in the gminas in the Wielkopolskie Voivodeship.

\section{Material and method}

The authors used in their research some results of the paper published previously by Beba and Kiryluk-Dryjska (2016), which identifies eight main factors characterizing agriculture and rural areas in north-western Poland, including the Wielkopolskie Voivodship, based on factor analysis ${ }^{11}$. These were: infrastructure, intensive farming, organic farming, entrepreneurship on rural areas, small-scale farming, quality of agricultural production space, animal production and demography. Table 1 presents the eigenvalues and the characteristics of these factors.

Table 1

The eigenvalue and percentage of variance explained by aggregated factors of rural and agriculture development in north-western Poland

\begin{tabular}{lcccc}
\hline \multirow{2}{*}{$\begin{array}{c}\text { Rural and agriculture } \\
\text { development factors }\end{array}$} & \multicolumn{4}{c}{ Breakdown: Main components } \\
\cline { 2 - 5 } & Eigenvalue & $\begin{array}{c}\text { \% of the total } \\
\text { variance }\end{array}$ & $\begin{array}{c}\text { Cumulative } \\
\text { eigenvalue }\end{array}$ & $\begin{array}{c}\text { Cumulative \% } \\
\text { of variance }\end{array}$ \\
\hline Infrastructure & 11.25 & 21.22 & 11.25 & 21.22 \\
Intensive farming & 5.54 & 10.46 & 16.79 & 31.68 \\
Organic farming & 3.60 & 6.79 & 20.38 & 38.46 \\
Entrepreneurship on rural areas & 3.32 & 6.27 & 23.71 & 44.73 \\
Small-scale farming & 2.51 & 4.73 & 26.21 & 49.46 \\
Valorisation index of agricultural & 2.44 & 4.60 & 28.65 & 54.05 \\
production space & 1.97 & 3.72 & 30.62 & 57.77 \\
Animal production & 1.75 & 3.30 & 32.37 & 61.07 \\
Demographic data & & & &
\end{tabular}

Source: Beba and Kiryluk-Dryjska (2016).

${ }^{11}$ The analysis was carried out based on 53 indicators describing the potential of agricultural and rural development in Poland. 
The study used in this paper covered 207 rural gminas and mixed urban-rural gminas in the Wielkopolskie Voivodeship. For each gmina, synthetic indicators describing agriculture and rural areas were determined in accordance with the method developed by Wysocki and Lyra (2007), taking variables referring to factors designated by Beba and Kiryluk-Dryjska (2016) as simple features ${ }^{12}$. For this purpose, the inhibitors and neutral variables were transformed into stimulants and their values were made comparable. Then, values of the synthetic features were determined for each of the factors by averaging the normalized values of simple features using the following formula:

$$
\bar{q}_{i}^{(1)}=\frac{\sum_{j=1}^{m} z_{i j}}{m} \quad(i=1,2, \ldots, n)
$$

where:

$z_{i j}$ - value of the normalized variable,

$n$ - number of researched objects,

$m$ - number of properties.

Synthetic indicators were calculated using single features for which correlation coefficient $\mathrm{R}$ was less than $0.5^{13}$. The thus obtained synthetic indicators characterized various elements of rural and agriculture development in the gminas of the Wielkopolskie Voivodeship.

Then, the percentage of farms applying for funds under the measure "Setting up of young farmers" provided for in the RDP 2007-2013 was calculated for each gmina in the Wielkopolskie Voivodeship, based on the ARMA's data relating to the number of applications submitted by farms in this respect. The obtained values were used as the measure of farmers' engagement in applying for funds under the measure "Setting up of young farmers". The publication was prepared based on selected scientific literature and unpublished data provided by the Agency for Restructuring and Modernization of Agriculture ${ }^{14}$.

The multiple stepwise regression method was applied to examine the impact of agriculture and rural features in the analysed gminas on farmers' engagement in applying for funds under the measure "Setting up of young farmers". The previously determined synthetic indicators of agriculture and rural development were used in the regression model as independent variables.

\footnotetext{
${ }^{12}$ The list of variables referring to the factors is presented in Beba and Kiryluk-Dryjska (2016). Variables were selected on the basis of literature review, mainly Bartkowiak and Poczta (2012), Stanny (2013), Rosner and Stanny (2014), Wójcik and Tomczyk (2015), Piszczek (2013), and Salamon (2005). The selection of variables was also conditional upon availability of data at the level of gminas. The data referred to 2010, i.e. the year of the last common agricultural census.

${ }^{13}$ In order to meet this condition, correlating features were omitted with respect to each factor designated by Beba and Kiryluk-Dryjska (2016). In the case of the infrastructure factor, these were: population density, pharmacies (per $100 \mathrm{~km}^{2}$ ) and the length of the sewerage system (per $100 \mathrm{~km}^{2}$ ). As regards the entrepreneurship on rural areas factor, the number of entities of national economy entered into the register per 1,000 people was omitted, and the average sown area was removed from the intensive farming factor. As regards other factors, the features were not excessively correlated, therefore, they were left unchanged.
}

${ }^{14}$ The figures come from the Wielkopolska Regional Branch of the ARMA as of December 2017. 
The core of multiple stepwise regression is the sequential elimination from the model of variables having an insignificant impact on the variability of the dependent variable, starting with the variable that is least correlated with it. The significance of each variable is evaluated using F-Snedecor statistics. The model is completely developed when all independent variables that have no significant impact on the dependent variable are eliminated from it (Stanisz, 2007).

\section{Findings}

Table 2 presents the first four steps of developing an empirical model of the impact of features characterising agriculture and rural areas on farmers' engagement in applying for funds under the measure "Setting up of young farmers". The following were successively eliminated from the model: small-scale farming, valorisation index of agricultural production space, animal production and demography. The first two eliminated variables had no statistically significant impact on the dependent variable ( $\mathrm{p}>0.05)$. The two further variables (animal production and infrastructure) affected the dependent variable, but their impact was negligible. The introduction of these variables into the model would have increased the value of the explained variance by less than $0.1 \%$. Table 3 presents statistical characteristics of the dependent variables used in the model.

Table 2

Summary of stepwise regression of dependent variable - engagement in applying for support under the measure "Setting up of young farmers"

\begin{tabular}{lcccccc}
\hline \multicolumn{1}{c}{ Indicator } & Step & $\begin{array}{c}\text { Spearman's } \\
\text { multiple }\end{array}$ & $\begin{array}{c}\text { R-square } \\
\text { multiple }\end{array}$ & $\begin{array}{c}\text { R-square } \\
\text { change }\end{array}$ & $\begin{array}{c}\text { F- to introduce/ } \\
\text { eliminate }\end{array}$ & $\mathrm{P}$ \\
\hline $\begin{array}{l}\text { Small-scale farming } \\
\begin{array}{l}\text { Valorisation index } \\
\text { of agricultural }\end{array}\end{array}$ & -1 & 0.7914 & 0.6262 & 0.0000 & 0.3348 & 0.5629 \\
$\begin{array}{l}\text { production space } \\
\begin{array}{l}\text { Animal production } \\
\text { Infrastructure }\end{array}\end{array}$ & -2 & 0.7913 & 0.6261 & -0.0001 & 2.1000 & 0.1473 \\
\hline
\end{tabular}

Source: authors' own study.

Table 3

Results of multivariate regression - percentage of farms applying for funds under the measure "Setting up of young farmers"

\begin{tabular}{lccccc}
\hline \multirow{2}{*}{ Indicator } & \multicolumn{4}{c}{$\mathrm{R}=0.79 \mathrm{R} 2=0.63 \mathrm{~F}(4.7334)=3,059$ standard error of the estimate 2.1545} \\
\cline { 2 - 6 } & $\mathrm{b}^{*}$ & $\begin{array}{c}\text { Standard error } \\
\text { with } \mathrm{b}^{*}\end{array}$ & $\mathrm{~B}$ & $\begin{array}{c}\text { Standard error } \\
\text { with B }\end{array}$ & $\mathrm{P}$ \\
\hline Intensive farming & 0.78 & 0.01 & 21.61 & 0.21 & 0.00 \\
Organic farming & -0.07 & 0.01 & -7.27 & 0.77 & 0.00 \\
$\begin{array}{l}\text { Entrepreneurship } \\
\text { on rural areas }\end{array}$ & -0.22 & 0.01 & -12.16 & 0.41 & 0.00 \\
Demographic data & 0.05 & 0.01 & 1.94 & 0.30 & 0.00 \\
\hline
\end{tabular}

$\mathrm{B}$ - regression coefficient; $b^{*}$ - standardized BETA coefficient

Source: authors' own study. 
The obtained model contains four variables (synthetic indicators) whose impact is statistically significant: intensive farming, organic farming, entrepreneurship on rural areas and demography. The model explains $63 \%$ of the variance of the dependent variable, and the created regression equation is as follows:

$$
\begin{gathered}
Y=21.6 x_{1}-7.3 x_{2}-12.2 x_{3}+1.9 x_{4} \\
R=0.79(R 2=0.63)
\end{gathered}
$$

where:

$y$ - the frequency of applying for funds under the measure "Setting up of young farmers" $(\%)$,

$x_{1}-$ intensive farming,

$x_{2}$ - organic farming,

$x_{3}$ - entrepreneurship on rural areas,

$x_{4}-$ demography.

The verification of the regression model includes analysis of residuals, which is an important stage of the verification process (Stanisz, 2007). Figure 1 shows a graph with normal distribution of residuals. The small and symmetrical distribution of residuals around the line indicates that the model meets the normality condition as regards the residuals, which confirms the significance of the model parameters.

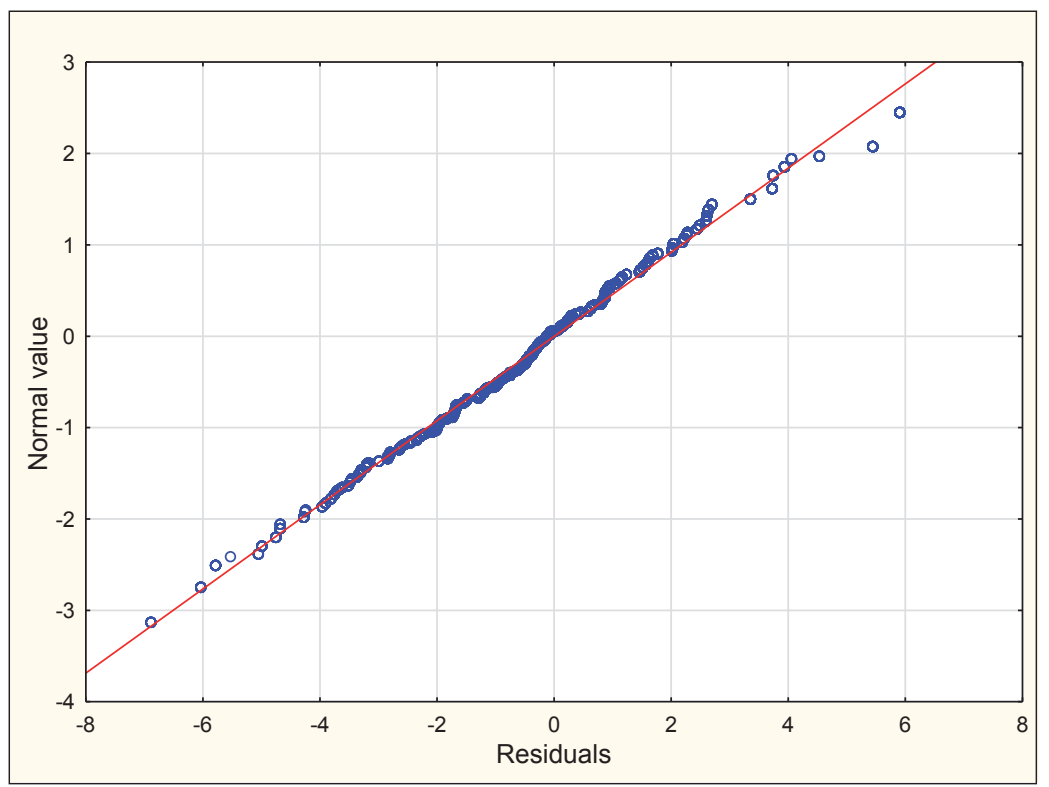

Fig. 1. Graph presenting the normality of residuals in the multivariate regression model. Source: authors' own study. 
The analysis of the data presented in Table 3 shows that intensive farming ${ }^{15}$ $\left(b^{*}=0.78\right)$ has the greatest impact on the dependent variable, i.e. the frequency of applying for funds under the measure "Setting up of young farmers". This is a positive impact, which means that the frequency of applying for funds under the measure "Setting up of young farmers" is greater in gminas characterized by robust and well-developed agriculture.

Demography is another indicator with a positive impact on the dependent variable, but its impact is definitely less significant ${ }^{16}$. In gminas with younger populations, as shown by the demographic indicator, engagement in applying for funds under the measure in question was higher.

There is, however, a negative correlation between the dependent variable and entrepreneurship on rural areas, expressed through the number of registered economic entities, and organic farming ${ }^{17}$. It needs to be noted that the negative impact of organic farming is weaker than that of entrepreneurship.

The regression results show that in the Wielkopolskie Voivodeship, the frequency of applying for funds under the measure "Setting up of young farmers" is higher on areas where intensive farming prevails and the demographic structure is favourable, and it is lower in gminas with well-developed entrepreneurship and organic farming.

\section{Discussion of results and conclusions}

In line with the guidelines included in the Regulation of the Minister of Agriculture and Rural Development on the detailed conditions and procedure for granting financial aid under the measure "Setting up of young farmers" covered by RDP for 2007-2013 (Journal of Laws of 2014, item 201). This measure was to contribute to encouraging young farmers to take up individual agricultural activities. This was to accelerate the change process in the agrarian structure of farms and boost competitiveness of the entire agricultural sector.

The paper presents results of regression which show that in the Wielkopolskie Voivodeship the frequency of applying for support under the measure "Setting up of young farmers" is higher than on areas where intensive agriculture prevails and the demographic structure is favourable. But it is lower in gminas of highly developed entrepreneurship and pursuing organic farming. It may be expected that in the researched area, intensification of the expected positive effects of action will depend on specific properties of agriculture and rural areas.

Positive correlation between the frequency of applying for funds under the measure "Setting up of young farmers" and the intensity of agriculture in the gminas in the Wielkopolskie Voivodeship are partly confirmed by the previously quoted stud-

\footnotetext{
${ }^{15}$ When calculating the synthetic index of intensive farming, the following simple features were taken into account: consumption of NPK fertilizers, percentage of industrial crops in total sown area, share of farms with an area of over 15 ha, number of tractors per farm.

${ }^{16}$ The demography index includes the children-elderly people relation and the total population growth (per 1,000 inhabitants).

${ }^{17}$ The organic farming synthetic measure includes the percentage of the number and area of organic farms relative to all farms.
} 
ies indicating a higher average area of the farms of the measure's beneficiaries in Poland ${ }^{18}$. These results are also consistent with the research by Dušek (2012) in Slovenia, showing that applications for bonus payments are submitted more frequently by future owners of large farms with a higher degree of agricultural production mechanization. It is, thus, reasonable to take this factor into account in predictions of farmers' engagement in applying for co-financing.

A positive impact of the demographic index on the activity in acquiring funds by farmers results from the very nature of support, and thus eligibility criteria for potential beneficiaries. It is available only to young farm owner, thus it enjoys much more interest among farmers on areas with a more favourable age structure. A negative relation between the entrepreneurship index and the frequency of applying for support under the studied measure may be indirectly explained by the fact that on areas predominated by agriculture there is, in general, less business operators registered than in gminas where the conditions for agriculture development are weaker. This correlation results from the function of the analysed rural areas. In typically agricultural gminas, the activity of farmers is higher than in gminas of more diversified functions. The negative impact of organic farming development on the activity in applying for funds under the analysed measure showed - on the basis of regression equation - that applicants for the measure "Setting up of young farmers" mainly come from areas, where organic farming developed rather poorly.

The proven substantive correctness of the factors used in the model and their logically substantiated impact allow for using the model in practice. The results produced by the model can be used in planning the rural development policy at the level of a single gmina, poviat or region.

At the level of gminas, information about the potential demand for funds under the "Young Farmer" programme can be obtained. This potential can be calculated using the equation presented in this paper, while the model can be used to demonstrate which gminas have a high and untapped potential in applying for the funds under the "Young Farmer" programme, and then find the reason(s) for this situation. Therefore, the research results may be used to target or intensify institutional measures motivating farmers to apply for funds from the EU.

By extending the scope of the analysis to larger administrative units, both positive and negative effects of the programme can be anticipated. The measure "Setting up of young farmers" is a programme designed to promote development, hence if farmers' engagement in this measure is greater in gminas where agriculture is well developed already at the onset of the programme, it can be expected that the process of polarization of rural and agricultural development, mentioned in the literature (see Sobecki, 2007; Bański and Czapiewski, 2008; Stanny, 2013), will only deepen. In other words, this measure may contribute to strengthening the agricultural sector in gminas where agriculture is already strong at the beginning. Research presented in the literature shows that most of funds supporting the agricultural sector are spent in areas with a relatively high level of agricultural development. On the other

\footnotetext{
${ }^{18}$ This also complies with the eligibility criteria for beneficiaries of support under the measure.
} 
hand, in less developed areas, where dispersed agriculture prevails, farmers are usually less likely to apply for support (Kiryluk-Dryjska, 2007). Therefore, as concluded by Wicki (2014), agricultural structures may be largely transformed due to stratification of farms. A group of agricultural enterprises producing the majority of agricultural output in Poland will emerge, while smaller farms will serve primarily social and residential functions. Michna (ed., 2008) predicts that spatial polarization will take place with respect to the area structure, agricultural production, income situation of farming families, sources of income and rural infrastructure.

Creation of a similar regression model for the whole country may enable targeting or reducing the process of farm polarization by setting the appropriate limit of regional funding of the measure components. If we assume that the rural and agricultural development policy is to prevent stratification, the limits in areas with weaker agriculture should be higher. Reverse targeting of support (higher limits in areas with more developed agriculture) should contribute to a faster transformation of agricultural structures, while leading to significant stratification of farms.

Summing up, the presented regression model can be a tool facilitating the implementation of an active rural and agricultural development policy. It can be used to intensify or reduce measures supporting the application for EU funds in territorial terms, and thus to target development processes in agriculture and rural areas. 


\section{References}

Adamowicz, M., Szepeluk, A. (2016). Wsparcie młodych rolników jako element polityki rolnej Unii Europejskiej. Zagadnienia Ekonomiki Rolnej, No. 3(348), pp. 106-128.

ARiMR (2014). Informacja o liczbie wydanych decyzji oraz kwocie zrealizowanych płatności w ramach działania „Ułatwianie startu młodym rolnikom” PROW 2007-2013. System Informacji Zarządczej ARiMR. Warszawa, Agencja Restrukturyzacji i Modernizacji Rolnictwa. Retrieved from: www.arimr.gov.pl/uploads/media/ 21072014_MR_7-13.pdf.

Bański, J., Czapiewski, K.Ł. (2008). Ekspertyza. Identyfikacja i ocena czynników sukcesu spoteczno-gospodarczego na obszarach wiejskich. Warszawa: Instytut Geografii i Przestrzennego Zagospodarowania PAN.

Bartkowiak, N., Poczta, W. (2012). Czynniki rozwoju obszarów wiejskich w Wielkopolsce. Poznań: Wydawnictwo Uniwersytetu Przyrodniczego w Poznaniu.

Beba, P., Kiryluk-Dryjska, E. (2016). Identyfikacja barier rozwoju wsi i rolnictwa w Polsce na przykładzie regionu północno-zachodniego. Prace Naukowe Uniwersytetu Ekonomicznego we Wrocławiu, no. 433, pp. 29-39.

Bielecka,D.(2006).Ocena organizacji systemu wdrażaniafunduszy pomocowych Unii Europejskiej. Czynniki wpływające na wykorzystanie funduszy pomocowych Unii Europejskiej przez gminy. Samorzad terytorialny, No. 6.

Brodzińska, K., Lewczuk, A. (2002). Charakterystyka gospodarstw młodych rolników. In: Z. Brodziński (ed.), Gospodarstwa młodych rolników w warunkach integracji europejskiej (pp. 61-74). Olsztyn: Wyd. Uniwersytetu Warmińsko-Mazurskiego.

Czubak, W., Kiryluk-Dryjska, E. (2009). Regionalne zróżnicowanie aktywności rolników w ubieganiu się o środki strukturalne UE przeznaczone na rozwój rolnictwa w Polsce w latach 2004-2006. Acta scientiarum polonorum, Oeconomia, No. 8 (3), pp. 13-24.

Dellapasqua, C. (2010). Young farmers and the EU's rural development policy. CEJA Conference on Multifunctional Agriculture, 15 December 2010.

Duška, H.K. (2012). Family farms in Slovenia: Who did the measures 'Setting Up of Young Farmers' and 'Early Retirement' actually address?. Anthropological Notebooks, vol. 18, issue 1, pp. 65-89.

Frye, D. (2013). Young farmers: Plan for financial success. Farm Future, 3, pp. 44-45.

Grontkowska, A., Frania, M., Bagieński, S. (2016). Ocena realizacji działania „Ułatwianie startu młodym rolnikom" Programu Rozwoju Obszarów Wiejskich 2007-2013 według województw. Roczniki Naukowe SERiA, vol. XVIII, issue 6, pp. 50-55.

Katchova, A., Ahearn, M. (2015). Farmland Assets and Growth Trends for Young and Beginning Farmers in the U.S. International Conference of Agricultural Economists "Agriculture in an interconnected world". Retrieved from: http://ageconsearch.umn.edu/record/211839/files/Katchova-Farmland\%20Assets\%20and\%20Growth\%20Trends\%20for\%20Young\%20 and\%20Beginning\%20Farmers-591.pdf.

Kiryluk-Dryjska, E. (2007). Macroregional differentiation of farmers' interest in Polish Rural Development Program measures in Poland. Roczniki Akademii Rolniczej w Poznaniu vol. CCCLXXXV, pp. 67-75.

Kozera, M. (2011). Regionalne zróżnicowanie wykorzystania środków pomocowych Unii Europejskiej. Roczniki Nauk Rolniczych, Seria G, vol. 98, issue 3, pp. 118-125.

Michna, W. (ed.). (2008). Raport o wpływie Wspólnej Polityki Rolnej na tendencję polaryzacji gospodarstw rolnych $w$ ramach poszczególnych regionów kraju. Warszawa: IERiGŻ-PIB.

Ministerstwo Rolnictwa i Rozwoju Wsi (2016). Program Rozwoju Obszarów Wiejskich na lata 2007-2013 (PROW 2007-2013). Warszawa. 
Miś, T. (2016). Pomoc dla młodych rolników z funduszy UE i ich wykorzystanie na przykładzie Podkarpacia. Zagadnienia Doradztwa Rolniczego, No. 2/2016, pp. 26-37.

Piszczek, S. (2013). Zróżnicowanie przestrzenne poziomu rozwoju społeczno-gospodarczego obszarów wiejskich województwa kujawsko-pomorskiego. Nierówności Społeczne a Wzrost Gospodarczy, No. 30, pp. 334-346.

Rosner, A., Stanny, M. (2014). Monitoring rozwoju obszarów wiejskich. Etap I. Przestrzenne zróżnicowanie poziomu rozwoju społeczno-gospodarczego obszarów wiejskich w 2010 roku (wersja pełna). Warszawa: EFRWP, IRWiR PAN.

Rozporządzenie Ministra Rolnictwa i Rozwoju Wsi z dnia 23 czerwca 2015 r. zmieniające rozporządzenie w sprawie szczegółowych warunków i trybu przyznawania pomocy finansowej w ramach działania „Ułatwianie startu młodym rolnikom” objętego Programem Rozwoju Obszarów Wiejskich na lata 2007-2013 (Journal of Lows of 2015, item 895).

Rozporządzenie z dnia 18 marca 2009 r. w sprawie podziału środków Programu Rozwoju Obszarów Wiejskich na lata 2007-2013, (Journal of Lows of 2009, No. 48, item 388).

Rudnicki, R. (2009). Demographic determinants of the activity of farms in Poland in the acquisition of European Union funds in the years 2004-2006. Bulletin of Geography. Socioeconomic Series, vol. 12, issue 12, pp. 45-59.

Rudnicki, R. (2013). Zróżnicowanie przestrzenne absorpcji funduszy Unii Europejskiej w rolnictwie polskim jako problem badawczy i aplikacyjny. Acta Universitatis Lodziensis Folia Geographica Socio-Oeconomica, No. 13, pp. 71-92.

Salamon, J. (2005). Badania wielofunkcyjnego rozwoju obszarów wiejskich województwa świętokrzyskiego. Infrastruktura i Ekologia Terenów Wiejskich, No. 4, pp. 145-155.

Sobiecki,R.(2007). Globalizacja a funkcje polskiego rolnictwa. Warszawa: Oficyna Wydawnicza SGH.

Stanisz, A. (2007). Przystepny kurs statystyki z zastosowaniem Statistica PL na przykładach z medycyny. Vol. 3: Analizy wielowymiarowe. Kraków: StatSoft Polska.

Stanny, M. (2013). Przestrzenne zróżnicowanie rozwoju obszarów wiejskich w Polsce. Warszawa: IRWiR PAN.

Wicki, L. (2014). Czynniki wpływające na częstość korzystania z wybranych działań PROW w gospodarstwach rolnych. Przeglad Zachodniopomorski, issue 3/2, pp. 93-103.

Wojewodzic, T. (2016). Czynniki różnicujące absorpcję wybranych działań PROW 2007-2013 w makroregionie Małopolska i Pogórze. Roczniki Naukowe Stowarzyszenia Ekonomistów Rolnictwa i Agrobiznesu, vol. XVIII, issue 2, pp. 290-295.

Wójcik, M., Tomczyk, J. (2015). Nierówności w poziomie rozwoju społeczno-gospodarczego gmin wiejskich województwa łódzkiego. Acta Universitatis Lodziensis. Folia Geographica Socio-Oeconomica, issue 20, pp. 85-100.

Wysocki, F., Lira, J. (2007). Statystyka opisowa. Poznań: Wydawnictwo Akademii Rolniczej.

Websites of the Agency for Restructuring and Modernization of Agriculture:

http://www.arimr.gov.pl/fileadmin/pliki/wdrazane_programy_sprawozdania/PROW_20072013/MR/27012016_MR_7-13.pdf. Access date: 25.03.2018.

http://www.arimr.gov.pl/fileadmin/_migrated/content_uploads/290610_SPO_rolny.pdf.

Access date: 25.03.2018.

http://www.arimr.gov.pl/fileadmin/pliki/zdjecia_strony/223/Sprawozdanie_ARiMR_2016.pdf. Access date: 06.05.2018. 


\title{
CZYNNIKI WPŁYWAJĄCE NA AKTYWNOŚĆ ROLNIKÓW W UBIEGANIU SIĘ O WSPARCIE Z DZIAŁANIA „UŁATWIANIE STARTU MŁODYM ROLNIKOM” W WOJEWÓDZTWIE WIELKOPOLSKIM
}

\begin{abstract}
Abstrakt
Celem pracy było wyznaczenie syntetycznych wskaźników rozwoju rolnictwa $i$ obszarów wiejskich różnicujacych aktywność rolników w ubieganiu sie o wsparcie z działania „Ułatwianie startu młodym rolnikom” PROW 2007-2013 $w$ gminach województwa wielkopolskiego. Badaniem objęto 207 gmin wiejskich $i$ miejsko-wiejskich. Dla każdej z gmin wyznaczono wskaźniki syntetyczne charakteryzujace rolnictwo i obszary wiejskie. Zaprezentowane wyniki badan wskazują, że częstość ubiegania się o środki unijne w ramach analizowanego działania przyjmuje większe wartości na obszarach, w których dominuje rolnictwo intensywne oraz wystepuje korzystna struktura demograficzna. Mniejsze natomiast w gminach o dobrze rozwiniętej przedsiębiorczości i rolnictwie ekologicznym.
\end{abstract}

Słowa kluczowe: Program Rozwoju Obszarów Wiejskich, ułatwianie startu młodym rolnikom, aktywność rolników.

Accepted for print: 18.12.2018.

Unless stated otherwise all the materials on the website are available under 